\title{
水平平行電極板間を飛昇する誘導帯電粒子群 のフラックスおよび粒子濃度
}

\author{
大久保豊*・高橋由樹**
}

\section{NKK 総合材料技術研究所 ${ }^{\dagger+}$}

\begin{abstract}
水平に置かれた平行平板の電極間において, 誘導帯電して飛昇する粉体粒子のフラック ス量と電極間の粒子濃度に関し，ポリウレタン樹脂粉とアルミナ粉を用いて実験的に調へ た.
\end{abstract}

上部電極下面に接着剤を塗布し，誘導帯電して飛昇し接着剤に付着する粒子重量を電圧 印可時間に対して調へ，得られた結果から付着重量の時間に関する回帰式を作成した。付 着重量の時間変化から求めた初期フラックス量が, 粒子の密度, 粒子径, 帯電して飛昇す る粒子のサイクル時間と本報で新たに提案する無次元の流量数で整理できることを明かに した.

また，電極間の粒子濃度に関するモデル式を構築し，この粒子濃度が，上電極への粒子 付着流量や電極内での粒子の循環時間によって定まることを明らかにした。

\section{緒}

粉体塗装における塗料の噴霧速度は, 生産性を支配す る重要な因子である。今日，多くはノズルガンを使用す る方式であるために塗装粉体の空間密度が低く数 $\mathrm{m} /$ $\min$ のコンベア速度しか得られていない. そこで，Ohkubo（Ohkubo and Takahashi, 1994）らは，鋼板を連 続して塗装するのに，水平平行に置いた電極板上の塗材 を誘導带電させて飛昇・塗着させる方式を提案した。こ の場合, 従来のノズル口が電極板の平面に取って代わる ので塗料粉の空間密度が著しく高くなり，高効率で塗装 が可能になる，筆者ら (Ohkubo and Takahashi, 1996) は本方式の基礎的特性を明かにすべく，これまでに，水 平平行な電極板間における粉体粒子の誘導带電にともな う飛昇に関する挙動を調べ（Wakamatsu，1991），飛昇 するときの臨界条件を示した。

本報では塗装能率を定量的に評価すべく，ポリウレ夕 ン樹脂粉とアルミナ粉を用い平行平板電極間で带電飛昇 する粉体の上電極面下面に塗られた接着剂に付着する重 量を時間毎に調べた。この結果を用いて粉体のフラック ス量について整理し, 初期フラックス量に及ばす粒子径, 粒子密度，代表時間などの関係を明らかにした。また， 電極間で循環するポリウレタン樹脂粉濃度を光透過法に

$\dagger 1996$ 年 8 月 16 日受理

†† $\bar{\top} 210$ 川崎市川崎区南渡田町 1-1

* 鋼管計測株式会社

** NKK 情報システム部
よって調べ，付着量や粒子の循環時間によって濃度が定 まることを明らかにした。

\section{1. 実験}

実験は誘導帯電して飛昇する粉体の流量を調べる目的 で，電圧印加にともない上電極に付着する粒子の重量変 化を計測する実験と，電極間で循環する粉体の挙動を調 べる目的で行った粉体の濃度に関する実験とに分けた。

\section{1 実験装置}

実験に用いた装置の概略を Fig. 1 に亦した。装置は上 電極板（溶融业鈖メッキ鋼板 $0.6 \mathrm{~mm}^{\mathrm{t}} \times 210 \mathrm{~mm}^{\mathrm{w}} \times 297$ $\mathrm{mm}^{1}$,メッキ厚み $60 \mathrm{~g} / \mathrm{m}^{2}$ 片面, ウレタン変性ポリエステ ル系樹脂を $5 \mu \mathrm{m}$ 被覆), 架台(脚はテフロン製, 台はア クリル製）の上に，この上電極板と水平平行に置かれた 下電極板（軟鋼板 SS 41, $3.2 \mathrm{~mm}^{\mathrm{t}} \times 350 \mathrm{~mm}^{\mathrm{w}} \times 350 \mathrm{~mm}$ 1), 试料粉体を乗せるためのベークライト板（日光化成 (株) 細糸布フエノ一ル樹脂積層板, $10 \mathrm{~mm}^{\mathrm{t}} \times 400 \mathrm{~mm}^{\mathrm{w}} \times$ $400 \mathrm{~mm}^{1}$ ), 直流高電圧発生器 (和光エンジニアリング 製, 最大出力 DC $100 \mathrm{kV})$, 上電極板を支持し下電極間の 距離を可変にするための鋼製フレーム（図示せず）から 成っている.

Fig. 2 は電極間で循環する粉体の濃度を調べるための 実験装置を模式的に示した困で，スライド用プロジェク ター (キャビン工業製, Pro Cabin 667, 入力 AC $100 \mathrm{~V}$, 電力 $650 \mathrm{~W}$ ), 前述した粉体の飛昇実験装置（Fig. 1 参 照)，アクリル製水槽 (内容積 : $300 \mathrm{~mm}^{1} \times 200 \mathrm{~mm}^{\mathrm{w}} \times 100$ $\mathrm{mm}^{\mathrm{h}}$ ), 光エネルギを計測する光パワーメーター(アドバ 
Table 1 Physical properties of powders used for the experiment

\begin{tabular}{lccccc}
\hline Powder & Density & Apparent density & Water fraction & Electric conductivity & Dielectric constant/conductivity \\
& $\rho_{\mathrm{p}}\left[\mathrm{kg} / \mathrm{m}^{3}\right]$ & $\gamma_{\mathrm{o}}\left[\mathrm{kg} / \mathrm{m}^{3}\right]$ & $\omega[-]$ & $\sigma\left[\Omega^{-1} \mathrm{~m}^{-1}\right]$ & $\tilde{\varepsilon} / \tilde{\sigma}[\mathrm{s}]$ \\
\hline Alumina & $4.0 \times 10^{3}$ & $1.74 \times 10^{3}$ & $2 \times 10^{-3}$ & $7.53 \times 10^{7}$ & $4.52 \times 10^{-5}$ \\
Poly-urethane & $1.0 \times 10^{3}$ & $0.55 \times 10^{3}$ & 0.04 & $1.20 \times 10^{-8}$ & $2.48 \times 10^{-2}$ \\
\hline
\end{tabular}

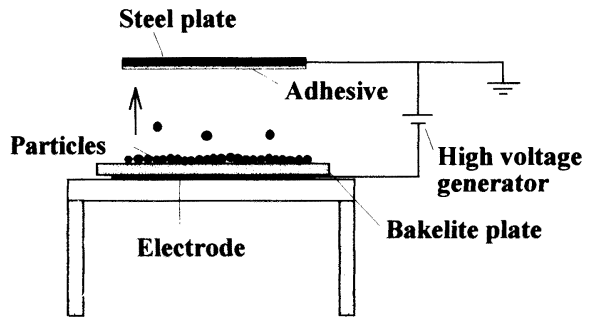

Fig. 1 Schematic diagram of lifting inductioncharged particles in horizontally set parallel plate electrodes

ンテスト製，TQ 8210)などから主に成立っている。また ここで，スリット状の開口部を持つ鋼板製の遮蔽板をプ ロジェクターの前に置き, 困中点線で示すスリット状の 水平光を得た。

実験に使用した試料は，アルミ十粉 (昭和電工(株)研 磨材 $45 \mathrm{~T}$ ), ポリウレタン樹脂粉 (藤倉化成 (株)) の 2 種 類で，あらかじめ振とう器によって分級し平均粒径で 2 水準（ポリウレタン樹脂粉： $59 \mu \mathrm{m}, 126 \mu \mathrm{m}$, アルミナ 粉： $64 \mu \mathrm{m}, 127 \mu \mathrm{m})$ を選んだ.ここで用いたアルミナ 粉は研磨布，研磨紙に使われている研磨材料で，表面に 酸化鉄のコーティングが施され電気伝導率が比較的高い 值をもち, 誘導带電されやすいように特性があらかじめ 調整されている。これに対して, ポリウレタン樹脂粉は, そのままでは電気伝導率が $10^{-12}(\Omega \mathrm{m})^{-1}$ と低く誘導帯 電され難い特性を持つ代表的な材料であり，加湿によっ て子预電気特性を調整した。それらの特性をまとめて Table 1 に示した。また表中の電気伝導率は，試作した測 定装置（Ohkubo and Takahashi, 1996 b）によって求め た. 水分率は島津製作所製水分計 (ED $200 \mathrm{MO})$ によっ て测定しな。

ただし，電極間の粉体濃度に関する実験は，前記粒子 の内, 平均径 $59 \mu \mathrm{m}$ のポリウレタン樹脂粉の場合につい てのみ実施した。

\section{2 実験方法}

まず上電極である鋼板に，バーコーター（ヨシミツ精 機(株)製\# 32)により，アクリルエマルション系の接着剂 (ダイヤボンド(株)製，DB-5807）をWet 膜厚で約 $45 \mu$ $\mathrm{m}$ 塗る。この時, 鋼板と塗布された接着剂を合わせた重 量を電子上血天科（島津製作所製 ED 200）によって科量 しておく。この後，速やかに上電極支持フレームに，下

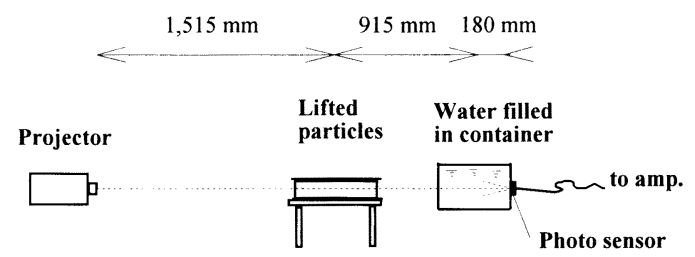

Fig. 2 Experimental apparatus for measurement of powder concentration in an electric field

電極と一定の間隔となるようにセットする.これに先立 ち既に分級してある粉体を，テーラー\#35の子るいを通 してべークライト板上に, 約 $1 \mathrm{~mm}$ の層厚となるまで散 布し，下電極上に乗せる.

ただし, ポリウレタン樹脂粉体の場合, 分級後あらか じめ市販の加湿器を用い水分を加湿調整した。これは既 報（Ohkubo and Takahashi, 1996 b) に示すように使用 したポリウレタン樹脂粉は電気導伝率が低くそのままで は電压を印可しても飛昇しなかったことによる。そこで $1 \%$ 以下の水分量を加湿によって $3 \sim 6 \%$ にした. 予め行 った試験によると,この水分量の蒸発速度は $0.3 \% / \mathrm{hr}$ で あり実験時間内でのこの蒸発の影響は無視できる。

次に所定の出力電圧に調整されている高電圧発生器よ り, 電圧を印加する。ただし, 電圧計測には集電式電位 測定器 (春日電気(株) 製 KS-525 型) を使用した. 電圧が 十分に高い場合，印加にともなって粒子はただちに上方 の陽極である鋼板の下面に向かって飛U゙始め, 接着剂層 中に取り込まれるが, やがて飽和する. 電圧印加開始か ら所定の時間の後, 試料粉が塗着している上電極の鋼板 を取り出し付着した粒子重量を測定した。

ポリウレタン樹脂粉の場合, 印加電圧は $40 \mathrm{kV}, 30$ $\mathrm{kV}, 20 \mathrm{kV}$ の 3 水準, 電極間距離は $40 \mathrm{~mm}$ 一定とした. また, アルミナ粉の場合, 印加電圧は $45 \mathrm{kV}, 30 \mathrm{kV}, 15$ $\mathrm{kV}$ の 3 水準, 電極間距離は $60 \mathrm{~mm}, 40 \mathrm{~mm}, 20 \mathrm{~mm}$ と した.

光を透過させ電極間での粒子濃度を計測する実験では， 電極間距離は $40 \mathrm{~mm}$ 一定とし, 印加電圧を $40 \mathrm{kV}, 30$ $\mathrm{kV}$ の 2 水準とした. 校正に当たっては水槽中に一定量 の粒子を懸濁させ，この時の光量を計測する方法を採っ た.この場合, 粉体の位置が水槽中と飛昇試験装置とで 異なるのを補償するために, 電極位置を光軸と平行に前 後 $250 \mathrm{~mm}$ ずらし粒子の位置の影響を調べた. 


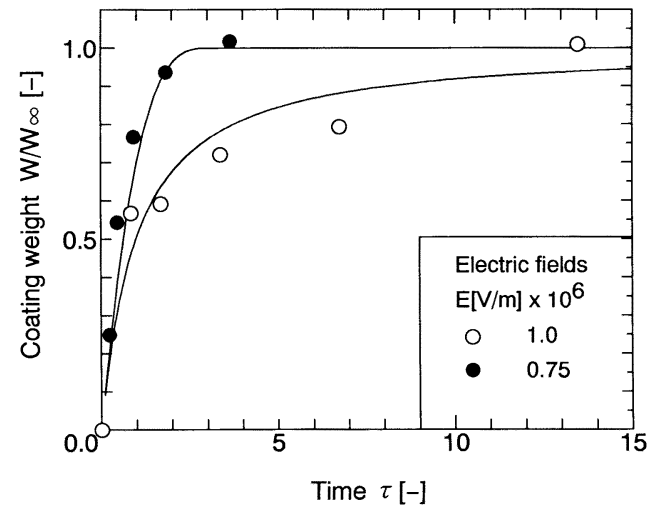

Fig. 3-1 Dimensionless coating weight vs time for the case of polyurethane $D_{p}=59 \mu \mathrm{m}$

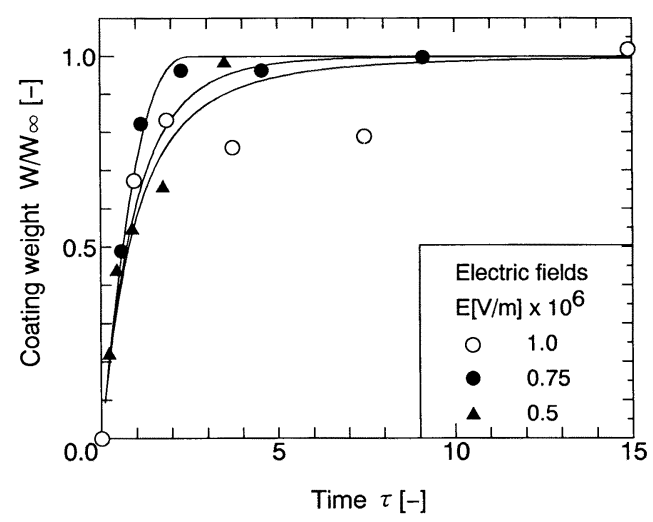

Fig. 3-2 Dimensionless coating weight vs time for the case of polyurethane $D_{p}=126 \mu \mathrm{m}$

\section{2. 実 験 結 果}

\section{1 粉体の付着流量}

電圧印可後の経過時間 $t$ に対して上電極鋼板下面に 付着した単位面積当たりの粒子の重量 $W$ は無限時間経 過後に期待される重量 $W_{\infty}$ で除して正規化 $\widetilde{W}(=W /$ $\left.W_{\infty}\right)$ し, 初期フラックス量 $q_{i 0}$ を用いた無次元時間 $\tau(=$ $\left.q_{i o} t / W_{\infty}\right)$ について整理した. ポリウレタン樹脂粉の平均 径 $59 \mu \mathrm{m}, 126 \mu \mathrm{m}$ についてのこの結果をそれぞれ Fig. 3 -1, Fig.3-2に，また，アルミ十粉の平均径, $64 \mu \mathrm{m}, 127$ $\mu \mathrm{m}$ についての結果をそれぞれFig. 4-1, Fig. 4-2 に示 した。時間の経過とともに粒子の付着重量が増加し, 数 時刻の内に飽和してしまうことがわかる。これは飛昇し て上電極に到達した粒子が鋼板面の接着㓮に捕獲され, その表面を覆い，やがて覆い尽くして飽和する過程を現 している. また, この様子は電界強度 $E$ や粒子径, 粒子 種によってやや異なっている.

ここでいうフラックス量は単位面積当たり接着剤面に

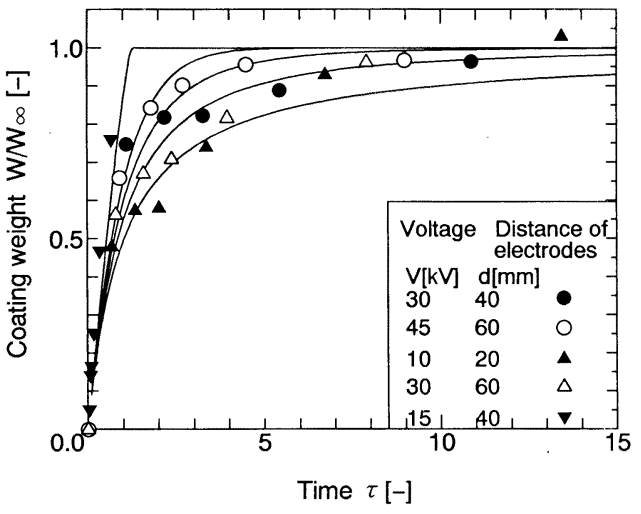

Fig. 4-1 Dimensionless coating weight vs time for the case of alumina $D_{p}=64 \mu \mathrm{m}$

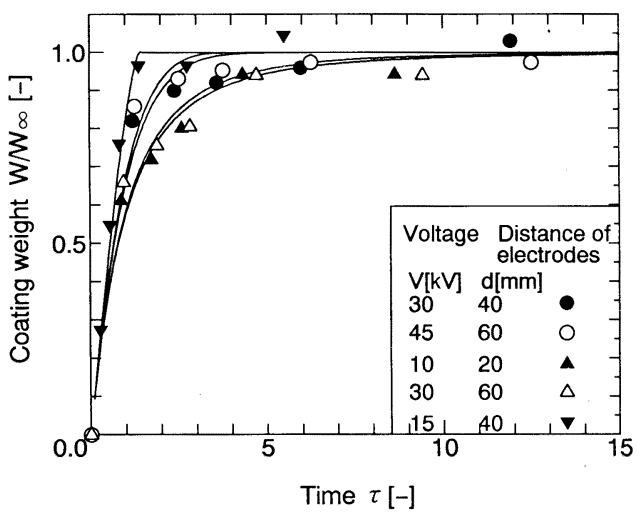

Fig. 4-2 Dimensionless coating weight vs time for the case of alumina $D_{p}=127 \mu \mathrm{m}$

衝突する粒子群の質量流量を意味している. 初期 $(t=0)$ は接着剂面に跳ね返る粒子が無視できるから，初期フラ ックス量は付着粒子重量の時間変化量に等しい，そこで 得られた付着量 $W$ のデータから差分法により $t=0$ に おける W の時間変化を求め初期フラックス量 $q_{i o}$ を得 た。また付着量の時間変化 $d W / d t$ を付着量 $W$ に対し てプロットし $d W / d t$ が 0 になる点を二次式で外挿した 時の付着量 $\mathrm{W}$ の值を $W_{\infty}$ とした。

困中実線は，次に示す方法によって求めた付着量に関 する回帰式を表している．付着量の時間変化 $d \widetilde{W} / d \tau$ は Eq. (1)に示すように付着量 $\widetilde{W}$ の関数で表されるものと する.

$$
d \widetilde{W} / d \tau=f(\widetilde{W})
$$

この微分方程式は $\widetilde{W}=0$ の場合 $d \widetilde{W} / d \tau=1$ となり, $\widetilde{W}=1$ で $d \widetilde{W} / d \tau=0$ となる. そこで, Eq. (1)の右辺を 1 - $\widetilde{W}$ のべき数で表されるものとして Eq. (2)に示す指 数 $n$ を実験結果より回帰して求めた.

$$
d \widetilde{W} / d \tau=(1-\widetilde{W})^{n}
$$




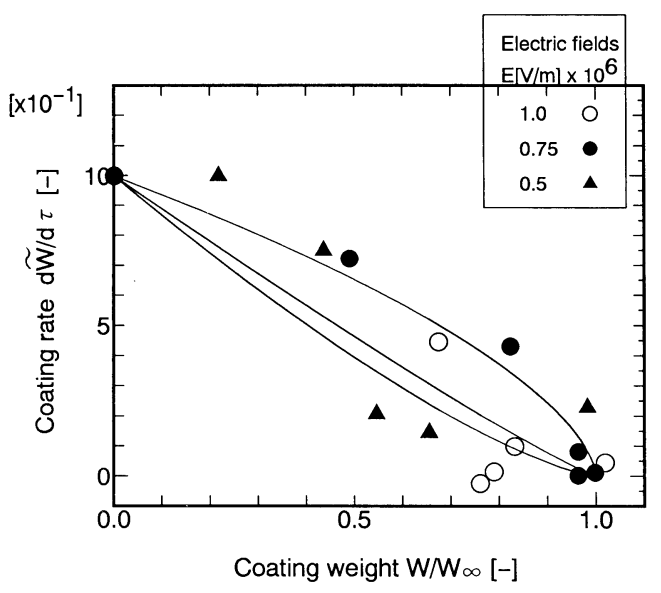

Fig. 5 Coating rate of powder with time for the case of polyurethane $D_{p}=126 \mu \mathrm{m}$

回帰した一例をFig.5に示した. Eq. (2)は解析的に解 け，Eq.(3)で表すことができる.

$$
\widetilde{W}=1-\{1-(1-n) \tau\}^{1 /(1-n)}
$$

Fig. 3-1, Fig. 3-2, Fig. 4-1, Fig. 4-2, 中の実線は Eq. （3）を図示したものである，付着重量 $\left(W / W_{\infty}\right)$ に関す る実験式 Eq. (3)によると, ポリウレタン樹脂粉の場合は 15\%の精度で, またアルミ十粉の場合は $12 \%$ の誤差精 度で実験值を推定できる。

次に初期フラックス量 $q_{i o}$ がどの様にして定まるか考 察してみる。電压が印加されると, 初女下電極上にある 粉体の最上層の粒子は時間の経過と共に帯電量を増し, この結果上方向に作用するクーロンカが大きくなる.(こ の力が自らの重力と水分の架橋力に打勝つと, 粒子は飛 昇するようになることを既に筆者らは明かにした.)この 最上段の粒子群が飛昇すると, その直下の粒子群が現れ て帯電が開始され，同様のプロセスを経て飛昇する。初 期の粒子群は互いに影響せず上昇するので，粒子群間の 時間差 $\Delta t$ はそのまま変わらずに粒子は上電極に衝突す るものと見なせる. 一段の単位面積当たりの粒子群の個 数を $N\left[\mathrm{~cm}^{-2}\right]$ とすると初期フラックス $q_{i o}$ は Eq. (4)で 表わされる。

$$
q_{i o}=N \pi \rho_{p} D_{p}{ }^{3} / 6 \Delta t
$$

ここで, $\rho_{p}$ は粒子密度, $D_{p}$ は粒子径, $\Delta t$ は帯電を始女 てから飛昇に要するまでの所要時間（サイクルタイム） をそれぞれ表している.また粒子数 $N$ は粒子断面積に逆 比例するから Eq. (5)で表される.

$$
N=k_{n} /\left(\pi D_{p}^{2} / 4\right)
$$

ただし， $k_{n}$ は比例定数である. Eqs. (4)- (5) から $N$ を消 去して整理すると Eq. (6)が得られる.

$$
q_{i o}=k D_{p} \rho_{p} / \Delta t
$$

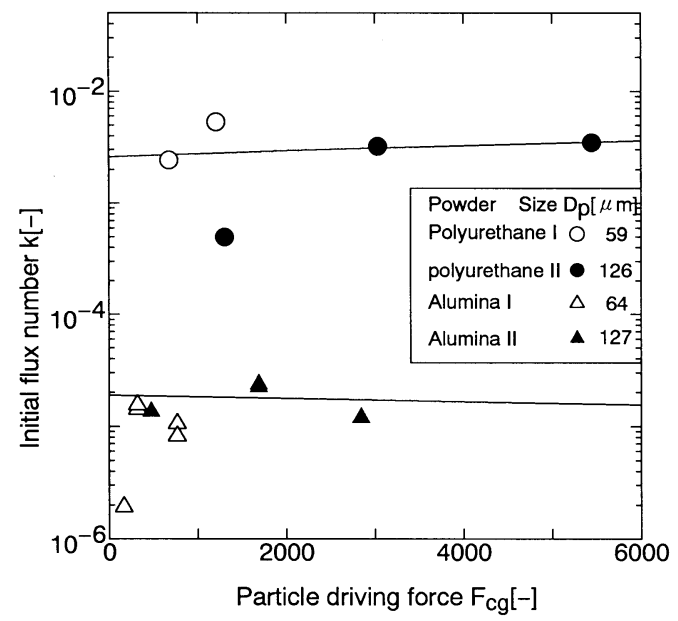

Fig. 6 Initial flux number $\mathrm{k}$ on the basis of cycle time for different driving forces

本報では以後これを初期流量数と呼ぶことにする.

このサイクルタイム $\Delta t$ は次のようにして求められる. 誘導带電によって粒子が飛昇する条件として次式 (Ohkubo and Takahashi, 1996 a) を考える.

$$
F_{c}[1-\exp (-t \tilde{\sigma} / \tilde{\varepsilon})]>F_{a}+F_{g}
$$

ただし $, F_{c}, F_{a}, F_{g}$ はそれぞれ Eqs. (8)-(10)で表わされ る.

$$
F_{c}=\pi^{3} D_{p}^{2}(1-\tilde{\varepsilon} / \tilde{\sigma}) \varepsilon_{2} E^{2} / 6
$$

ただし，本式の適用範囲は $10^{-5} \mathrm{~m}<D_{p}<3 \times 10^{-4} \mathrm{~m} 10^{4}$ $V / \mathrm{m}<E<E^{*} V / \mathrm{m}, E^{*}$ は放電限界 (Meek and Craggs, 1953), $0<\tilde{\varepsilon} / \tilde{\sigma}<1$.

$$
F_{a}=0.025 T \sqrt{\omega \rho_{p} / \rho_{\omega}} D_{p}
$$

また，本式は $0<\omega<0.15$ の範囲で得られた。

$$
F_{g}=\pi D_{p}^{3} \rho_{p} g /\{6(1-\omega)\}
$$

式中 $\tilde{\varepsilon}, \tilde{\sigma}$ は，それぞれ粉体層の見かけの誘電率 $\varepsilon$, 見 かけの電気導電率 $\sigma$ を空気の誘電率 $\varepsilon_{2}$, 見掛けの電気伝 導率 $\sigma_{2}$ で除し無次元化している. 粉体層の水分の影響は 後述するように考慮したが，蒸発の影響が無視できるの で空気層での水分の影響は考慮していない.ここで，空 気の見掛けの電気伝導率は $20 \mathrm{~mm} \phi$ の電極 (間隔 $5 \mathrm{~mm}$ ) に6,000 V を加え $10^{-10} \mathrm{~A}$ を得た結果 (Miyoshi, 1986) から, $\sigma_{2}=2.65 \times 10^{-13}(\Omega \mathrm{m})^{-1}$ とした. Eq. (8) 中, $\tilde{\varepsilon} / \tilde{\sigma}$ の内 $\sigma$ は実測值に基づく值のみ使用し, $\tilde{\varepsilon}$ は Lichteneckerの対数混合則を使い筆者らが提案 (Ohkubo and Takahashi, 1996 a) した次式の予測式に基いた.

$$
\tilde{\varepsilon}=\tilde{\varepsilon}_{\mathrm{p}}{ }^{\left(\gamma_{0} / \rho_{\mathrm{p}}\right)} \cdot \tilde{\varepsilon}_{\omega}{ }^{{ }^{k \omega} \omega\left(\gamma_{0} / \rho_{\omega}\right)}
$$

$E$ は電界の強さ, $\omega$ は水分率, $g$ は重力加速度をそれぞ れ表している. Eq. (7) 中の時間 $t$ をサクルタイム $\Delta t$ で置き換え, Eq. (7)の両辺を等置して $\Delta t$ で書き直すと 


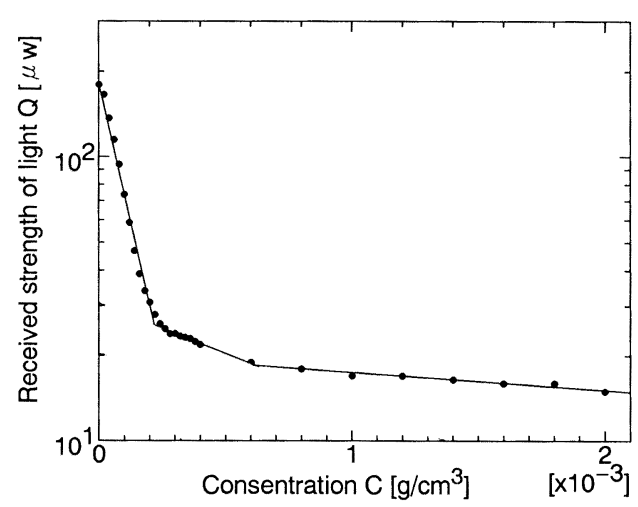

Fig. 7 Relations between particle concentration in water vessel and strenght of light through the layer

Eq. (12)が得られる.

$$
\Delta t=(1-\tilde{\varepsilon} / \tilde{\sigma}) \ln \left[1-\left(F_{a}+F_{g}\right) / F_{c}\right]
$$

ただし, $F_{a}+F_{g}<F_{c}$

Eq. (12) を用いて Eq. (6) 中の流量数 $k$ を求め, この結 果を次式で表わされる無次元数 $F_{c g}$

$$
F_{c g}=6\left(F_{c}-F_{g}\right) \rho_{f} /\left(\pi \mu_{f}^{2}\right)
$$

について整理し Fig. 6 に図示した.ここで, 式中 $\rho_{\mathrm{f}}, \mu_{f}$ は空気の密度や粘度をそれぞれ表している。

計算に用いた值を Table 1 にまとめて示した. Fig. 6 によるとポリウレタン樹脂粉とアルミ十粉とで固有の流 量数があるのがわかる．既報において筆者らが示したよ うに，ポリウレタン樹脂粉とアルミ十粉とでは電気特性 $\tilde{\varepsilon} / \tilde{\sigma}$ (Table 1 参照)が大きく異なり，ポリウレタン樹脂 粉に比べてアルミ十粉の方がより低電界で飛昇し，同じ 電界ではアルミ十の方が初期フラックス量が大きい。ア ルミナの方がより飛昇しやすい様子は，サイクル時間を 見てもアルミ十の方がより少ない時間となっていること からも良く分かる. 本提案の初期流量数は, 初期フラッ クス量とサイクル時間の積であるから，電気特性が異な っても一定值をとることが期待されたが，両者で異なる 值となった。これは，初期流量数が各サイクルにおいて 飛昇する粒子数を表しているから，下部電極上での粒子 の立填率などが因子に含まれていることなどが影響して いるためと考之られる。この様に初期流量数は粒子の種 類によって異なる值をとり得るから，Fig. 6 に示される 差が現れたと考えることができる。

\section{2 電極間における粉体の濃度}

Fig. 7 は飛昇する粒子が電極間で循環する時の粒子濃 度を光透過法によって調べるに先立ち, 水槽中に一定量 のウレタン粒子を入れ，透過する光エネルギーと粒子濃 度との関係について得られた結果で，デー夕は 3 本の直 線で近似できる。この様に粒子濃度に対して光の透過特

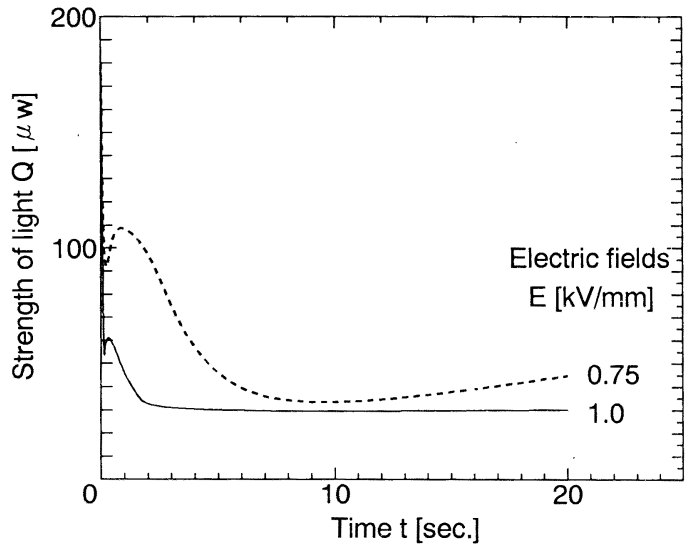

Fig. 8-1 Experimental results of light through powder for the case of polyurethane $\left(D_{p}: 59 \mu \mathrm{m}, \omega: 0.03\right.$, with adhesion)

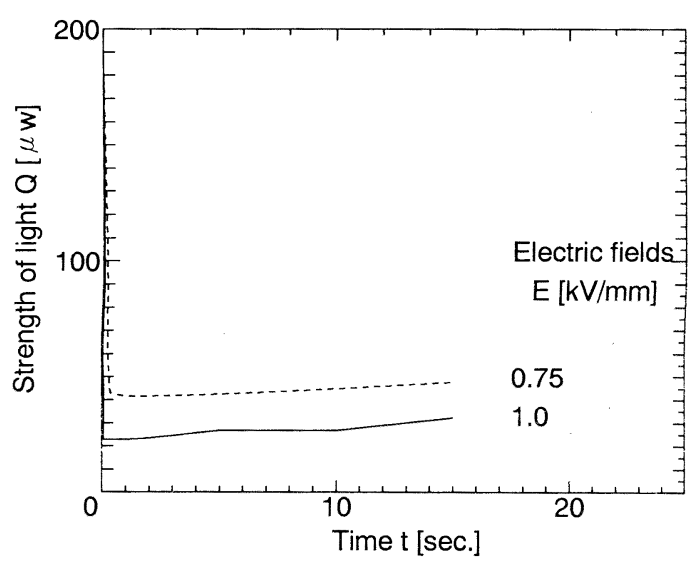

Fig. 8-2 Experimental results of light through powder for the case of polyurethane $\left(D_{p}: 59 \mu \mathrm{m}, \omega\right.$ : 0.03 , without adhesion)

性が異なるのは，受光部から見て光源が見える領域と見 えない領域に分けられることによる。これらの結果に粉 体位置の影響を補正し光エネルギーを粒子濃度に換算し た。

Fig. 8-1, Fig. 8-2 は平均径 $59 \mu \mathrm{m}$ のポリウレタン樹 脂粉を電界強度 $E$ が $10^{6} \mathrm{~V} / \mathrm{m}$ と $7.5 \times 10^{5} \mathrm{~V} / \mathrm{m}$ のをと で飛昇する粒子層を透過した光エネルギの電圧印加後の 様子を上電極に接着剤を塗布した場合と, 塗布していな い場合とに分けてそれぞれ示した，接着郕の付いていな い場合は急速に光が遮られるのに対して，接着剤が塗ら れている場合は光の透過量が一定值を示すまでにより長 い時間がかかっている，また電界強度が高いほど，定常 に㧍ける光の透過量は少なくなり粒子がより高濃度にな っている。

Fig. 9に示すように電極間における粒子について物質 
Table 2 Experimental Results

\begin{tabular}{lclcccccc}
\hline \multicolumn{1}{c}{ Powder } & $\begin{array}{c}\text { Dia. } \\
D_{\mathrm{p}}[\mu \mathrm{m}]\end{array}$ & $\begin{array}{c}\text { Electric field } \\
E[\mathrm{~V} / \mathrm{m}]\end{array}$ & $F_{\mathrm{cg}}[-]$ & $\begin{array}{c}\text { Flux number } \\
k[-]\end{array}$ & $\begin{array}{c}\text { Flux } \\
q_{\text {io }}\left[\mathrm{g} / \mathrm{cm}^{2} \mathrm{~s}\right]\end{array}$ & $n[-]$ & $\begin{array}{c}\text { Cycle time } \\
\Delta t[\mathrm{~s}]\end{array}$ & $W_{\infty}[\mathrm{g}]$ \\
\hline Polyurethane & 59 & $1 . \mathrm{E}+06$ & 1203. & $5.35 \mathrm{E}-03$ & $8.42 \mathrm{E}-03$ & 1.93 & $3.75 \mathrm{E}-03$ & 6.24 \\
Polyurethane & 59 & $0.75 \mathrm{E}+06$ & 673. & $2.45 \mathrm{E}-03$ & $2.04 \mathrm{E}-03$ & 0.671 & $7.11 \mathrm{E}-03$ & 5.60 \\
Polyurethane & 126 & $1 . \mathrm{E}+06$ & 5445. & $3.51 \mathrm{E}-03$ & $1.04 \mathrm{E}-02$ & 1.34 & $1.99 \mathrm{E}-03$ & 6.97 \\
Polyurethane & 126 & $0.75 \mathrm{E}+06$ & 3027. & $3.23 \mathrm{E}-03$ & $5.21 \mathrm{E}-03$ & 0.613 & $3.66 \mathrm{E}-03$ & 5.71 \\
Polyurethane & 126 & $0.5 \mathrm{E}+06$ & 1300. & $4.98 \mathrm{E}-04$ & $3.21 \mathrm{E}-04$ & 1.11 & $9.15 \mathrm{E}-03$ & 0.916 \\
Alumina & 64 & $0.75 \mathrm{E}+06$ & 761. & $1.06 \mathrm{E}-05$ & $3.45 \mathrm{E}-02$ & 1.22 & $7.28 \mathrm{E}-06$ & 19.8 \\
Alumina & 64 & $0.75 \mathrm{E}+06$ & 761. & $8.21 \mathrm{E}-06$ & $2.66 \mathrm{E}-02$ & 0.930 & $7.28 \mathrm{E}-06$ & 18.5 \\
Alumina & 64 & $0.5 \mathrm{E}+06$ & 315. & $1.42 \mathrm{E}-05$ & $1.82 \mathrm{E}-02$ & 2.06 & $1.84 \mathrm{E}-05$ & 16.9 \\
Alumina & 64 & $0.5 \mathrm{E}+06$ & 315. & $1.56 \mathrm{E}-05$ & $2.00 \mathrm{E}-02$ & 1.56 & $1.84 \mathrm{E}-05$ & 15.8 \\
Alumina & 64 & $0.375 \mathrm{E}+06$ & 160. & $1.94 \mathrm{E}-06$ & $1.12 \mathrm{E}-03$ & 0.201 & $4.09 \mathrm{E}-05$ & 20.9 \\
Alumina & 127 & $0.75 \mathrm{E}+06$ & 2838. & $1.20 \mathrm{E}-05$ & $3.84 \mathrm{E}-02$ & 0.881 & $7.38 \mathrm{E}-06$ & 20.1 \\
Alumina & 127 & $0.75 \mathrm{E}+06$ & 2838. & $1.20 \mathrm{E}-05$ & $3.83 \mathrm{E}-02$ & 0.786 & $7.38 \mathrm{E}-06$ & 19.1 \\
Alumina & 127 & $0.5 \mathrm{E}+06$ & 1683. & $2.26 \mathrm{E}-05$ & $2.85 \mathrm{E}-02$ & 1.28 & $1.87 \mathrm{E}-05$ & 20.6 \\
Alumina & 127 & $0.5 \mathrm{E}+06$ & 1683. & $2.39 \mathrm{E}-05$ & $3.02 \mathrm{E}-02$ & 1.35 & $1.87 \mathrm{E}-05$ & 20.0 \\
Alumina & 127 & $0.375 \mathrm{E}+06$ & 469. & $1.36 \mathrm{E}-05$ & $7.70 \mathrm{E}-03$ & 0.289 & $4.17 \mathrm{E}-05$ & 17.5 \\
\hline
\end{tabular}

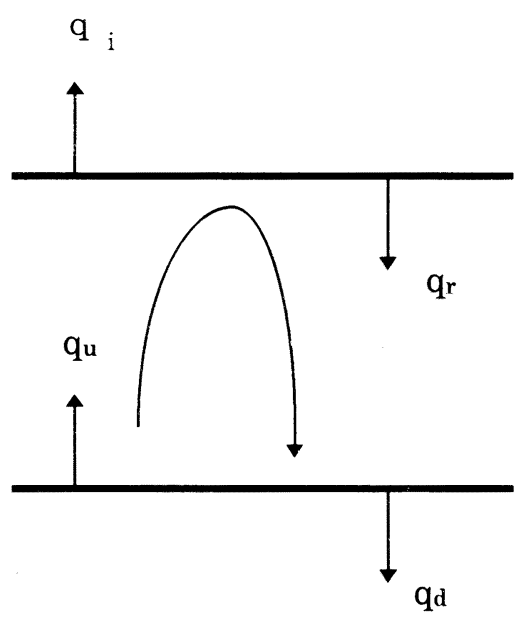

Fig. 9 Schematic diagram of particle flow between electrodes

収支をとると Eq. (14) が得られる.

$$
H d C / d t=q_{u}-q_{d}-\left(q_{i}-q_{r}\right)
$$

ここで $H$ は電極間距離, $C$ は粒子平均濃度, $q_{u}$ は下部電 極より上暴する粒子のフラックス， $q_{d}$ は下部電極へ戻る 粒子のフラックス， $q_{i}$ は上部電極に衝突する粒子のフラ ックス， $q_{r}$ は上部電極に跳ね返って電極間に戻る粒子の フラックス（既に付着した粒子のはがれるものも含む）， をそれぞれ表している．電圧印加後，粒子が上昇して上 電極に到達する以前では， $q_{d} ， q_{i}, q_{r}$ はいずれも 0 であ るから, Eq.(14)は $q_{u}$ を $q_{i o}$ に等しく,かつ一定として解 くことができ，解として Eq. (15)が得られる.

$$
0 \leqq t<t_{L 1} \text { の時, } C=q_{i o} t / H
$$

ここで, $t_{L 1}$ は粒子が上電極までに到達する時間を表して いる，さらに粒子が上電極に到達してから一部はね返り

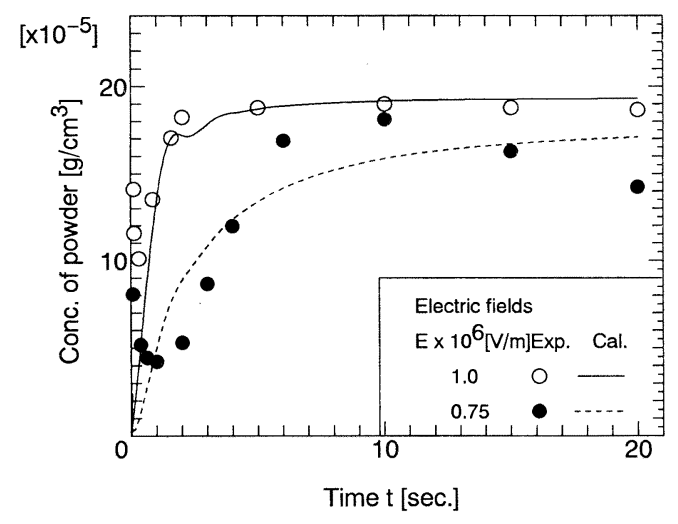

Fig .10 Comparison of numerical models and experimental results for concentration of powder between electrodes

下部電極までに戻る時間 $t_{L 2}$ では， $q_{d}$ は 0 であり， $q_{i}-q_{r}$ は $d W / d t$ に等しいから次式が成立つ.

$t_{L 1} \leqq t<t_{L 1}+t_{L 2}$ の時,

$H d C / d t=q_{i o}-d W / d t$

これを解いて，

$$
C=C_{L 1}+\left\{q_{i o}\left(t-t_{L 1}\right)-W\right\} / H
$$

ただし， $C_{L 1}=q_{i o} t_{L 1} / H$

$t_{L 1}+t_{L 2} \leqq t$ の時, $q_{d}=q_{i o}-d W /\left.d t\right|_{t-t_{L 2}}$ が成立つから Eq. (14)は Eq. (18) で表せ，これを解くと Eq. (19)が得ら れる.

$$
\begin{aligned}
& H d C / d t=d W /\left.d t\right|_{t-t_{L 2}}-d W /\left.d t\right|_{t} \\
& C=C_{L 1+L 2}+\left\{\left(W_{t-t_{L 1}}-W_{t_{L 1}}\right)-\left(W_{t}-W_{t_{L 1}+t_{L 2}}\right)\right\} / H
\end{aligned}
$$

ただし, $C_{L 1+L 2}=C_{L 1}+\left(q_{i o} t_{L 2}-W_{t_{L 1}+t_{L 2}}\right) / H, W_{t-t_{L 1}}$, $W_{t_{L 1}}, W_{t}, W_{\mathrm{t}_{L 1}+t_{L 2}}$ などは各添え字の時刻における付着量 
Wを表している.

時間 $t_{L 1}, t_{L 2}$ がわかれば Eq. (3), Eq. (15), Eq. (17), Eq. (19) から粒子濃度を見積もることができる.ここで 時間 $t_{L 1}, t_{L 2}$ を次に示す方法で求めた. 上電極に接着剂が 塗られていない場合, 衝突して再び下部電極に戻る. Fig. 8-2に現れている濃度の定常值までの遅れ時間は， $t_{L 1}+$ $t_{L 2}$ に等しいとみなせる.図よりこの遅れ時間は電界強度 $E$ によって異なり, $E$ が $10^{6} \mathrm{~V} / \mathrm{m}, 7.5 \times 10^{5} \mathrm{~V} / \mathrm{m}$ に対し て, 遅れ時間は 0.069 秒, 0.262 秒となっている. 筆者ら が既に提案している方法 (Ohkubo and Takahashi, 1996 c）に従って,帯電して上昇する粒子が上電極に到達する までの時間 $t_{L 1}$ を解析的に求めると, 前記の電界強度に 対して，0.008 秒，0.0115秒がそれぞれ得られ，これより $t_{L 2}$ は 0.061 秒, 0.25 秒となる.これらの值を用い推定し た粒子濃度と実験の結果とを比較して Fig. 10 に示した。 計算值と実験值はよく一致しており本モデルによって良 く粒子濃度が推定できることが分かる.

\section{結言}

平行平板の電極間において，誘導带電して飛昇する粉 体粒子が接着剂の塗られている上電極に付着する場合,

この付着量，および電極間での粒子濃度が時間と其にど の様に変化するかを実験的に明らかにした。実験は A 4 判サイズの電極板を使い，接着剂の塗られている上電極 に付着するポリウレタン樹脂，またはアルミ十粉の粒子 重量を時間ごと計测した。また電極間で粒子濃度が粒子 の飛昇に伴ってどのように変化するかを透過光量を測定 して求めた。この結果, 以下の結論か得られた。

1）付着粒子重量 $\widetilde{W}$ は時間 $\tau$ と共に增加するが，すぐ に飽和し，この様子は次式で表わされる。ただし $n$ は定 数.

$\widetilde{W}=1-\{1-(1-n) \tau\}^{1 /(1-n)}$

2）初期フラックス量は粒子径，粒子密度，サイクル時

間，無次元化して得られる流量数などによって表される.

3）本報で新たに提案するこの流量数は，粒子種類によ って固有の值を示した。

4）電極間の粒子濃度は前 1）項の付着挙動を示す式と 粒子の循環の時間とから推定できる.

\section{Nomenclature}

$C=$ concentration of powder

$D_{p}=$ particle diameter

$\left[\mathrm{g} / \mathrm{cm}^{3}\right]$

$E=$ intensity of electric field

$F_{a}=$ adhesion force

$F_{c}=$ coulomb force

$F_{g}=$ gravity force
$F_{c g}=$ dimensionless external force

$[-]$

$g \quad=$ gravity acceleration

$k=$ flux number

$k_{n}=$ coefficient in Eq. (5)

$k_{\omega}=$ coefficient in Eq. (11)

$N=$ lifted number of particle

$n=$ coefficient in Eq. (2)

$q_{i o}=$ initial flux

$t$ = time

$t_{L 1}=$ travel time from bottom to top

$t_{L 2}=$ travel time from top to bottom

$T=$ surface tension

$V=$ voltage

$W=$ powder coated weight

$W=$ dimensionless powder coated weight

$\left[\mathrm{m} / \mathrm{s}^{2}\right]$

$[-]$

$[-]$

$[-]$

$\left[\mathrm{cm}^{-2}\right]$

$[-]$

$\left[\mathrm{g} / \mathrm{cm}^{2} \mathrm{~s}\right]$

[s]

[s]

$[\mathrm{s}]$

$\left[\mathrm{N} / \mathrm{m}^{2}\right]$

$[\mathrm{V}]$

$\left[\mathrm{g} / \mathrm{cm}^{2}\right]$

$[-]$

$\Delta t=$ cycle time

$\gamma_{0}=$ apparent density of powder layer

[s]

$\varepsilon=$ dimensionless dielectric constant

$\left[\mathrm{kg} / \mathrm{m}^{3}\right]$

$\iota_{f}=$ viscosity of air

$\rho=$ density

$\sigma=$ dimensionless electric conductivity

$\omega=$ water fraction

〈Subscript〉

$f \quad=$ fluid

io $=$ initial

p = particle

$\omega=$ water

$\infty=$ long period of time

\section{Literature cited}

Meek, J. M. and J. D. Craggs; Electrical Breakdown of Gases, Clarendon Press, Oxford, UK (1953)

Miyoshi, Y.; "Houdenkaishi no Igi," Seidenkigakkaishi, 10, 543-551 (1986)

Ohkubo, Y., Y. Takahashi, T. Fuga, K. Ohsawa, N. Gunji and H. Ishimura ; "High Quality Fashionable Steel by New Electrostatic Powder Coating Method," NKK gihou, No. 146, 25-32 (1994)

Ohkubo, Y. and Y. Takahashi ; "Lifting Criteria of an Induc. tion-Charged Spherical Particle in a Field with Horizontally Set Parallel Plate Electrodes," Kagaku Kogaku Ronbunshu, 22, 113-119 (1996 a)

Ohkubo, Y. and Y. Takahashi ; "Experimental Investigation on Lifting Criteria of an Induction-Charged Spherical Particle in a Field with Horizontally Set Parallel Plate Electrodes," Kagaku Kogaku Ronbunshu, 22, 603-609 (1996 b)

Ohkubo, Y. and Y. Takahashi ; "Lifting Velocity of an Induction-Charged Alumina Particle in Horizontally Set Parallel Plate Electrodes," Kagaku Kogaku Ronbunshu, 22, $1222-1229$ (1996 c)

Wakamatsu, T.; “Seidenbunri," Funtaikongakkaishi, 28, 57522 (1991) 


\title{
Flux and Particle Concentration of Induction-Charged Powder Coating in a Field with Horizontally Set Parallel Plate Electrodes
}

\author{
Yutaka Ohkubo* and Yoshiki Takahashi**
}

Research and Development Division, NKK CORPORATION, Kawasaki 100

Key Words: Powder Coating, Induction Charge, Horizontally Electrodes, Flux, Concentration of Powder

Experimental and numerical approachs are taken to investigate the flux and concentration of powders lifted by induction-charge in a field with horizontally set parallel plate electrodes.

The weight of the powders, lifted and attached to an adhesive on the upper electrode, is measured at certain time when a high voltage is supplied. The powder flux is obtained by taking the derivative of the coating weight of particles and gives a formula for the coating powder weight by integrating a curve which fits the data for the flux. It is found that the value for an initial flux of powder is composed of the density and diameter of the particle, calculated lifting cycle time, and proposed dimensionless flux number.

The concentration of the lifted powders between electrodes is examined by using light to measure the density of the powder layer. The proposed theoretical formula for the concentration of powders is almost identical to the experimental results.

* Kokankeisoku Corpration

** Information System Department, NKK CORPORATION 